Artigo Original

\title{
Hydro-sedimentological computational tool: case study of the Mogi-Guaçu SHP (Brazil-SP)
}

\author{
Ferramenta computacional hidrossedimentológica: estudo de caso da PCH de Mogi-Guaçu(Brazil-SP) \\ Bruno Bernardo dos Santos', Renato Billia de Miranda", Tainá Thomassim Guimarães"I', \\ Carlos E. N. Medina Martinez ${ }^{\mathrm{IV}}$, Claudio Bielenki Juniorv, Frederico Fábio Mauad ${ }^{\mathrm{VI}}$
}

\section{Abstract}

The hydro-sedimentological studies are complex and of great importance, mostly in countries with large amounts of water resources and with its energy matrix predominantly hydraulic. The assessment of the amount of sediment carried through water bodies is more difficult mainly due to the amount of involved quantities, which require the adoption of probabilistic or deterministic estimation methods. In this context, this paper presents a case study that applies the hydros-sedimentological module from the computational tool NH Statistic and Sediment, developed by one of the authors, written in Visual Basic for Applications to determine total sediment discharge using data from the Mogi-Guaçu Small Hydro Electric Power Plant (SP-Brazil). Among the surveys, the reduction of total sediment discharge was verified, which was expected. Likewise, the results provided by the developed computational tool were compared to the results of other softwares showing minimal differences, giving validity and consistency to the applied method. It's worth mentioning that the method used in this case study may be replicated in other places, giving more information to assist the water resource management.

Keywords: Hydro-sedimentology; Total sediment discharge; Computational tool; Visual basic for Applications

\section{Resumo}

Os estudos hidrossedimentológicos são complexos e de grande importância principalmente em países com grande quantidade de recursos hídricos e com matriz energética predominantemente hidráulica. A determinação da quantidade de sedimento transportada em um corpo hídrico é dificultada principalmente devido à maior quantidade de grandezas intervenientes, o que requer a aplicação de métodos de estimativa probabilísticos ou determinísticos. Nesse contexto, este artigo apresenta um estudo de caso empregando o módulo hidrossedimentológico da ferramenta computacional NH Statistic and Sediment, desenvolvida por um dos autores, com linguagem de programação em Visual Basic for Applications para a determinação da descarga sólida total a partir dos dados obtidos na Pequena Central Hidrelétrica de Mogi-Guaçu (SP-Brazil). Foi verificada a redução da descarga sólida total no reservatório entre as campanhas, resultados esses condizentes com o esperado. Além disso, comparando-se os resultados fornecidos pela ferramenta computacional desenvolvida com outros softwares, as diferenças foram mínimas e comprovam a validade e consistência do método implementado. Ressalta-se também que a metodologia utilizada no estudo de caso pode ser replicada para outros locais, proporcionando mais informações para a gestão e planejamento de recursos hídricos.

Palavras-chave: Hidrossedimentologia; Descarga sólida total; Ferramenta computacional; Visual basic for Applications

\footnotetext{
$\vee$ PhD in Environmental Engineering Sciences, Center for Water Resources and Environmental Studies, University of São Paulo, São Carlos, SP, Brazil bbernardo49@gmail.com; claudio@ana.gov.br

PhD in Environmental Engineering Sciences, Postgraduate Program in Environmental Engineering Sciences Professor of University of São Paulo, Center for Water Resources and Environmental Studies, University of São Paulo, São Carlos, SP, Brazil - rbm1706@gmail.com

III MSc in Environmental Engineering Sciences, Center for Water Resources and Environmental Studies, University of São Paulo, São Carlos, SP, Brazil tainathomg@usp.br

MSc Candidate of the Postgraduate Program in Environmental Engineering Sciences, Center for Water Resources and Environmental Studies, University of São Paulo, São Carlos, SP, Brazil - carlos.martinez@usp.br

" PhD in Energy Systems Planning, Postgraduate Program in Environmental Engineering Sciences Professor of University of São Paulo, Center for Water Resources and Environmental Studies, University of São Paulo, São Carlos, SP, Brazil
} 


\section{Introduction}

Brazil has one of the biggest hydro energetic reserves in the world, along with a vast amount of world's fresh water. This resource is mainly used for irrigation, storage and electric power generation, which require hydro-sedimentological analysis the knowledge of the water body, indispensable to its water resource management and correct use. Moreover, the hydro-sedimentological processes demand sediment detailed studies and its interactions with the environment, an important theme of economical, social and ecological interest.

Syvistki et al. (2005) claim that environmental issues related to sediments are particularly important in developing countries, since its population growth rate is usually high and this increase is proportional to the pressure over natural resources, which causes the rates of production and deposition of sediment to rise. Once it is present in the aquatic ecosystem, it plays an important role to the biota supplying nutrients and energy. Besides, sediment performs as a water quality regulator due to its capacity to withhold and release pollutants (GOLTERMAN; SLY; THOMAS, 1983). According to Carvalho (2008) and Vanoni (1975), the sediment transport may: jeopardize all the water uses; interfere with the light penetration and the heat in the water bodies; needed to the photosynthesis and salubrity in the water bodies; act as carriers for other pollutants; cause abrasion in electromechanical equipment and hydraulic structures; and provoke disturbances in the channel shape.

Generically, according to Branco e Rocha (1977) e Muller (1995), all watercourses have the intrinsic property to transport sediments, whether suspended, saltation, rolling or a combination of these ways. The sediment transport in water is ruled by the relation between the water discharge carrying capacity and the strength needed to shift the solid particles available in its course (LIMA; SILVA, 2007).

Curtis, Culbertson e Chase (1973) used data from 27 drainage basins in USA could estimate the yearly average sediment discharge that reached the oceans. The results pointed that 14.2 million of tons per day of sediment reached the Atlantic Ocean, 378.179 million reached the Gulf of Mexico, and 99.1 million reached the Pacific Ocean. Furthermore, to Curtis, Culbertson e Chase (1973) and Holeman (1968), it is estimated that in USA only about $10 \%$ of eroded material in the drainage basins reach oceans, while the rest is deposited in lakes, reservoirs, channels and land surface. Syvitski et al. (2005) verified that 12.6 billion of tons of sediment per year are carried worldwide in water bodies, considering that reservoirs trap $20 \%$ of global sediment inflow due mostly to the deposition and yield.

According to Silva e Wilson Júnior (2005), the sediment discharge estimate in a river is probably one of the most complexes problems in all fluvial hydraulics. The suspended load is always easily attained. The biggest difficulty, according to Carvalho (2008) e Paiva (2001), is in the assessment of bed and total load as a result of more quantities involved. They can be classified as de- terministic processes, which use equations to estimate these processes, or in stochastic processes (probability) that use data acquired in field work to analyze the correlation between the involved variables.

Among the most known estimate methods of total sediment discharge worldwide are the Modified Einstein Procedure by Colby and Hembre (1955) and the Simplified Procedure by Colby (1957). The former procedure is a probabilistic method, result of several years of research of shallow and deep rivers in Nebraska, USA. In this case, suspended load measures and bed load gathering are needed, which requires lots of information and the use of abacuses (Santos, et al., 2012). The latter procedure by Colby (1957) to estimate total sediment discharge is based on Einstein's procedure and in several field measurements. In this assessment, the total sediment discharge is separated in measured and unmeasured; the first is easily calculated using total sediment discharge equations, meanwhile the second is estimated using abacuses.

However, to Alonso, Neibling e Foster (1981), the forethought of sediment transport rates significantly differs between the formulas, which turns the choosing of a reliable equation to estimate a specific load difficult. Scapin, Paiva e Beling (2007) found that the Procedures, both the Modified Einstein and Colby, that incorporate suspended sediment concentration measured data, provided the best results in a section from the river Arroio Cancela in Santa Maria (RS).

Considering the total sediment discharge estimation procedures' potential to support hydro-sedimentological studies, a case study was made using a hydro-sedimentological module from a computational tool developed by one of its authors, written in Visual Basic for Applications (VBA) to determine the total sediment discharge using data acquired from the Mogi-Guaçu Small Hydro Electric Power Plant (SP-Brazil).

This study is part of a project from the Technological Research and Development Program from Electrical Energy Sector (P\&D ANEEL) through a partnership between São Carlos School of Engineering, Foundation for the Research Increase and the Industrial Improvement (FIPAI) and the Energy Company AES Tietê, the latter being the project's sponsor.

\section{Materials and Methods}

\subsection{Study area characterization}

The study area to gather the required data to the computational tool tests was the reservoir from the Mogi-Guaçu Small Hydro Electric Power Plant. It is located in Mogi-Guaçu drainage basin (22 $22^{\prime} 45.6^{\prime \prime} \mathrm{S}$; $46^{\circ} 53^{\prime} 59,1^{\prime}$ W), and belongs to Water Resources Management Unity 9 (UGRHI - 9) (Figure 1).

The Mogi-Guaçu Small Hydro Electric Power Plant (SP-Brazil) is located in the Alto Mogi sub-drainage basin, between the cities Mogi-Guaçu and Mogi-Mirim. The river Mogi-Guaçu gives its name to both to the city and the undertaking, that has a head of $11.6 \mathrm{~m}$ and 7.2 MW of installed capacity power (Figure 2). It 
Figure 1 - State of São Paulo Water Resources Management Unities

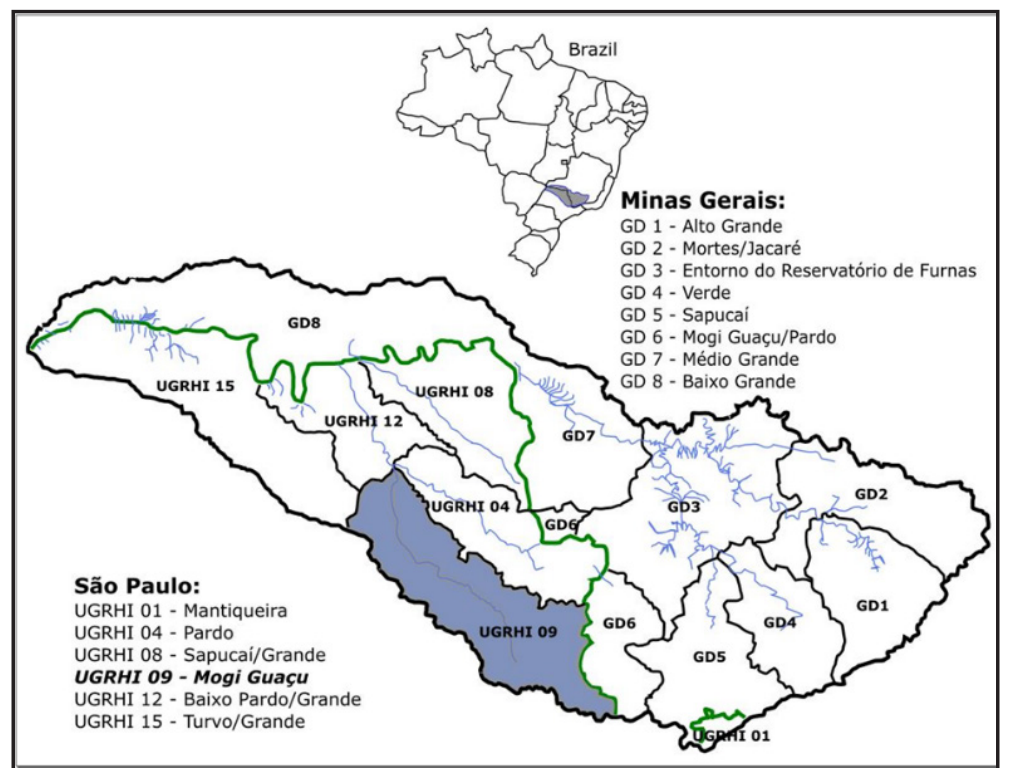

Source: Santos et al. (2018)

Figure 2 - Mogi-Guaçu Small Hydro Electric Power Plant aerial view

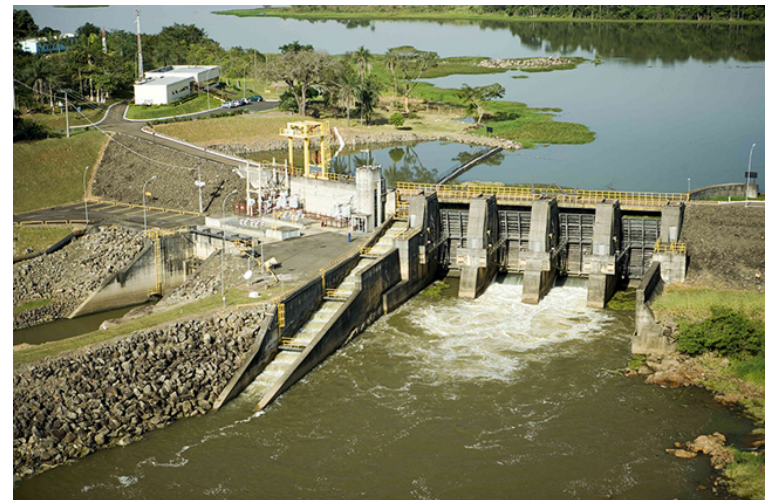

Source: AES Tietê (2018)

was originally owned by Companhia Energética de São Paulo (CESP) but was later acquired by AES Tietê in late 90's during the great privatization of the electric power industry and remains under the concession of this company (Table 1).

According to CBH Mogi (2008), the waters from the
Mogi-Guaçu Small Hydropower Plant's reservoir are ranked as Class 2, its surroundings is mostly used to plant sugar cane with small pasture areas and coffee plant cultivation. Its influence area is in a zone identified as of high susceptibility to erosion, as well as a large portion of the reservoir's drainage basin area.

Table 1 - Mogi-Guaçu (SP) Small Hydropower Plant Characteristics

\begin{tabular}{|c|c|c|c|}
\hline \multicolumn{4}{|c|}{ Mogi-Guaçu (SP) Small Hydropower Plant Technical Characteristics } \\
\hline Operation start & 1994 & Installed capacity power & $7.2 \mathrm{MW}$ \\
\hline Location & Mogi-Guaçu river & Turbines & 2 \\
\hline Flooded area & $5.73 \mathrm{~km}^{2}$ & Nominal voltage & $13.8 \mathrm{kV}$ \\
\hline Volume & $32.89 \times 10^{6} \mathrm{~m}^{3}$ & Maximum operating water level & $598.5 \mathrm{~m}$ \\
\hline Dam length & $150 m$ & Minimum operating water level & $596 m$ \\
\hline $\begin{array}{l}\text { Total water discharge in the } \\
\text { spillway }\end{array}$ & $2,099 \mathrm{~m}^{3} \cdot \mathrm{s}^{-1}$ & Sluice gate & No \\
\hline
\end{tabular}


Other than the electric power generation, the dam also damps the peak flood of rain episodes and provide for the cities Mogi-Mirim and Mogi-Guaçu. Both towns have high susceptibility areas in their urban area to floods throughout the Mogi-Guaçu river banks downstream of the dam.

\subsection{Primary data gathering}

Primary data gathering in the Mogi-Guaçu reservoir took place in two surveys. The first one, representing the rainy season, happened on January 25, 27, 28 and 29, 2014. The second one, representing the drought season, happened on March 18, 19 and 20, 2014.

For that, the reservoir was strategically divided into 20 sampling locations for a better understanding of the sediment transport throughout it, whereas each location was located approximately over the talweg (Figure 3). Moreover, measurements were made throughout the cross section on locations 12, 14, 16 and 20, located in the reservoir's main channel. It is worth noting that on the second survey, there were algae preventing the access to location 20, therefore the measurements were up to location 19.

Figure 3 - Mogi-Guaçu reservoir sampling locations

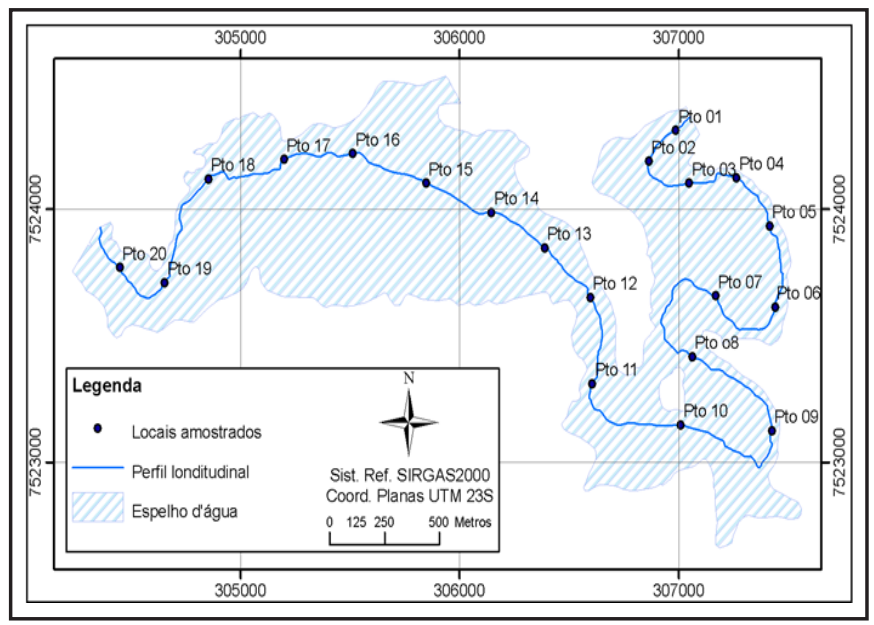

Source: FIPAI (2015)

The precise location of the sampling locations was obtained using a high precision GPS receptor, model GS20, with an antenna, model AT 201 from Leica Geosystems, that was installed along a $1,200 \mathrm{kHZ}$ ADCP. The ADCP was coupled besides the ship pointing downwards, approximately $40 \mathrm{~cm}$ deep (Figure 4). ADCPs uses the Doppler Effect, assess the water discharge mean direction, projecting the velocity onto a normal plane in this direction. This projection allows the calculation of the water discharge. In short, the ADCP supplied hydraulic data for width, depth, total section area, velocity, water discharge, among other information. The measurements were done two to four times in the same section to obtain a mean value, reminding that the ADCP can't measure all the cross section.
Figure 4 - ADCP assembly design with GPS antenna inside the boat (Above); ADP not yet submerged (Bellow)

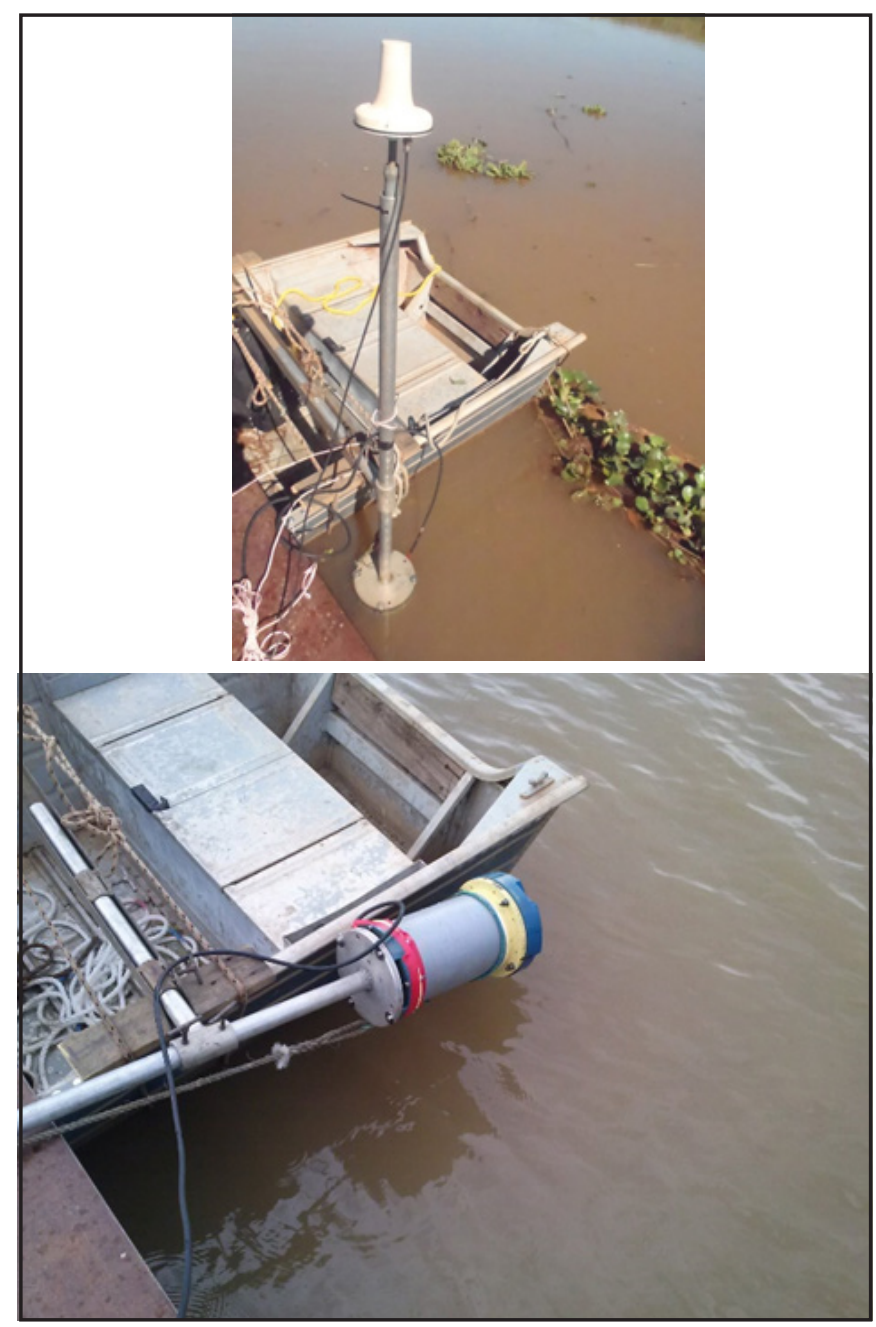

Source: Authors

Samples of the suspended sediment concentration (SSC) were collected using the Van Dorn Bottle to sample water-sediment at the surface, approximately 1 meter deep, and close to the bottom, at least $0.5 \mathrm{~m}$ distant from the riverbed). All procedures to determine the concentration of suspended solids were carried out following the norms and procedures proposed in the Standard Methods for Examination of Water and Wastewater (APHA, 1995).

\subsection{Total sediment discharge calculation's implementation}

The computational tool (NH Statistic and Sediment) was written in Visual Basic for Applications (VBA) programming language. This type of language was chosen due to the abundance and flexibility of its features, and mainly due to the great availability and ease of access, user-friendly and intuitive interface, including interactivity with Access ${ }^{\circledR}$ databases.

Among the methods to determine and assess the total sediment discharge, Colby's simplified procedure (COLBY, 1957) was chosen. According to Miranda (2015), this method compared to the Einstein procedure modified by Colby and Hembree (1955) requires less data, which 
makes it more economical and easier, precisely by the reduction of field and laboratory work.

Colby (1957) showed correlations between unmeasured sediment discharge with mean velocity and concentration and verified the possibility of these correlations being successfully applied to several types of sediment assessments. Thus, the total sediment discharge is given by Equation 1.

$$
Q_{s t}=Q_{s m}+Q_{n m}
$$

$$
\begin{aligned}
& \text { Where: } \\
& \mathrm{Q}_{\mathrm{st}}=\text { total sediment discharge [t.day }{ }^{-1} \text {; } \\
& \left.\mathrm{Q}_{\mathrm{ss}}=\text { measured sediment [t.day }{ }^{-1}\right] \text {; } \\
& \mathrm{Q}_{\mathrm{nm}}=\text { unmeasured sediment [t.day }{ }^{-1} \text {; }
\end{aligned}
$$

The measured sediment $\left(\mathrm{Q}_{\mathrm{sm}}\right)$ can be obtained by calculating the suspended load (Equation 2). However, the unmeasured sediment (Qnm), given by Equation 3, which represents the integration of bed load with unmeasured load, is estimated with the aid of abacuses, knowing the mean velocity (ms-1), depth (m), measured concentration (ppm) and section width (m) (CARVALHO, 2008).

$$
\begin{aligned}
Q_{s m} & =0.0864 \cdot Q \cdot C S S \\
Q_{n m} & =q_{n m}^{\prime} \cdot k \cdot L
\end{aligned}
$$

Where:

$Q \quad=$ water discharge $\left[\mathrm{m}^{3} \cdot \mathrm{s}^{-1}\right]$;

CSS = measured or sampled concentration $[\mathrm{ppm}=$ $\mathrm{mg} . \mathrm{L}^{-1}$;

$q_{n m}=$ unmeasured sediment per one meter of the

water body's cross section width $\left[\right.$ t.day $\left.{ }^{-1} \cdot \mathrm{m}^{-1}\right]$;

$L \quad=$ sampled cross section width [m];

$k=$ correction factor [dimensionless];

Figure 5 contains the Abacus 1 of the simplified procedure by Colby (1957). In it, it is possible to obtain the unmeasured sediment per meter of width of the water body from the mean water discharge velocity. The software Engauge Digitizer developed by Mitchell et al. (2018) was used to obtain a representative equation for Abacus 1, which automatically retrieves data points from graphs, thus allowing an equation to be coded in VBA (Equation 4).

$$
\log \log q_{n m}^{\prime}=3.340 \cdot \log \log V+1.617
$$

After that, it was still necessary to determine the correction factor k, obtained from Abacus 2 and 3. Figure 5 presents Abacus 2 that allows the relative concentration $(\mathrm{Cr})$ to be obtained using velocity and mean depth. In this case, the equations used for Abacus 2 coding were listed by Paiva (1988).

According to the author, the relative concentration is given by Equation 5 .

$$
\log \log C_{r}=A \cdot \log \log V+B
$$

Where:

$C_{r} \quad=$ Relative concentration $\left[\mathrm{ppm}=\mathrm{mg} \cdot \mathrm{L}^{-1}\right] ;$

$A$ e $B=$ Standard values to obtain $\mathrm{Cr}$ data by Paiva (1988, p.275)

Figure 5 - Abacus 1: Acquiring of unmeasured sediment discharge per one meter of the water body's cross section width using mean velocity (Above); Abacus 2: Acquiring of relative sediment concentration using mean velocity and mean depth (Bellow)
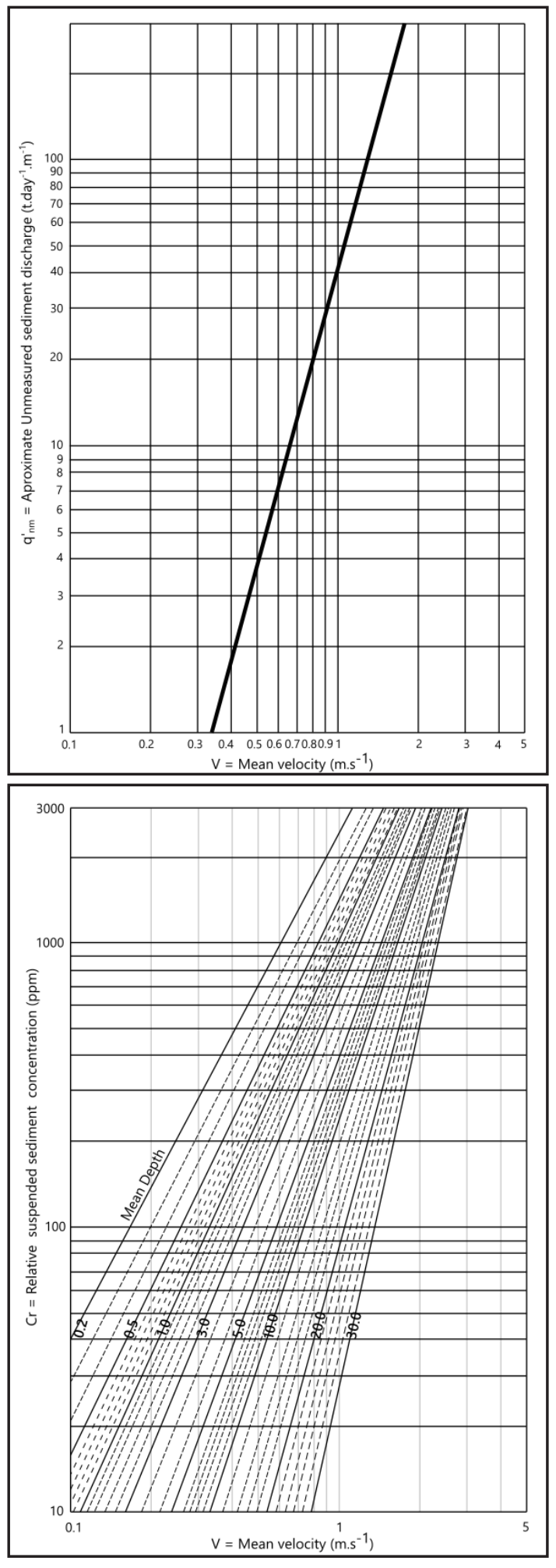

Source: Adapted from Carvalho (2008) and Paiva (2001) 
After determining the relative concentration $(\mathrm{Cr})$, from Equation 6 it was possible to determine the efficiency ratio $(\mathrm{Re})$ given by the ratio of the measured concentration to the relative concentration. Thus, through Abacus 3, we could determine the correction factor $\mathrm{k}$ (Figure 6).

$$
R e=\frac{S S C}{C_{r}}
$$

Figure 6 - Abacus 3: Acquiring correction factor using availability ratio

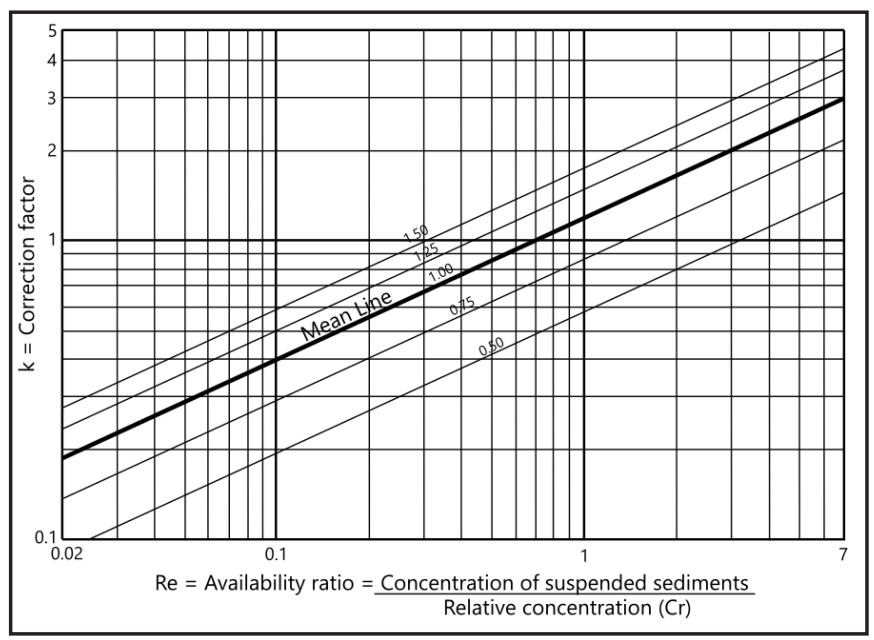

Source: Adapted from Carvalho (2008) and Paiva (2001)

As in previous abacuses, according to Colby (1957), abacus 3 represents the wide range of cross sections and concentrations measured in several rivers such as Mississippi, Colorado and Niobrara in the United States. Therefore, the mean line represents the location of most of the 262 points plotted in the author's study, which makes it the best curve for this application. In this case, the Engauge Digitizer software was used to determine the mean line equation in Abacus 3 (Equation 7).

$$
\log \log k=0.4819 \cdot \log \log R e+0.0739
$$

Knowing all the procedure that involves the estimation of total sediment discharge as well as the equations that rule it, the Colby procedure (1957) in the computational tool was implemented in VBA code, allowing the Qst to be estimated for different sections of the Mogi-Guaçu reservoir.

\section{Results and Discussion}

Figures 7 and 8 illustrate some of the water discharge and velocity profiles obtained in the measurements of the hydraulic characteristics of the Mogi-Guaçu reservoir sections, respectively at the entrance of the reservoir and near the dam.

Analyzing the velocity profiles, it is clear that the water discharge intensity in the broader sections in both campaigns decreased. The cell velocities in section 1 were observed mostly between 0.0 and $0.3 \mathrm{~m} . \mathrm{s}^{-1}$, while in sections
19 and 20 cell velocities were between -0.1 and $0.1 \mathrm{~m} \cdot \mathrm{s}^{-1}$. It is worth noting that negative velocity values indicate that the water discharge is in the opposite direction, which is present in flooded areas resulting from natural turbulence of the water bodies. The results of the hydraulic and sedimentological characteristics are presented in Tables 2 and 3, respectively, for the first and second surveys. Table 3 - Hydraulic characteristics' measurements of Mogi-Guaçu's reservoir in the second survey

Figure 7: (a) Estimated water discharge and velocity: Section 1 second measurement in the first survey; and (b) Section 1 first measurement in the second survey

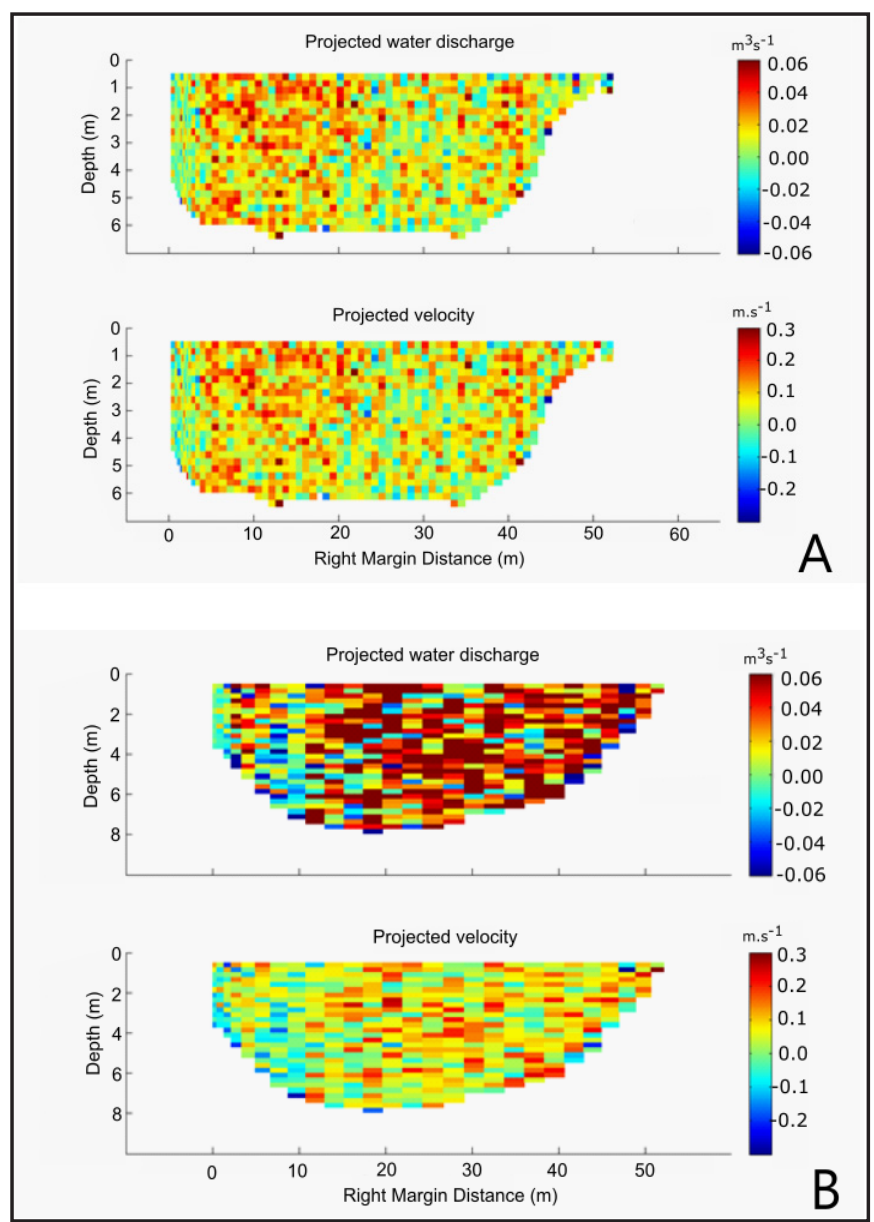

Source: FIPAI

With the exception of the results of section 16, it was noticed that the water discharge in all the sections presented similar results, ranging from 20.76 to 28.67 $\mathrm{m}^{3} \cdot \mathrm{s}^{-1}$. Regarding section 16 , because of its greater width in the reservoir along with the intensity of the winds, that varies between 0.219 and $0.533 \mathrm{~m} . \mathrm{s}^{-1}$ in the first campaign and 0.780 and $1.256 \mathrm{~m} . \mathrm{s}^{-1}$ in the second one, there were difficulties in measuring because of the waves formed in the reservoir that prevented the ADCP from being vertical $100 \%$ of the time, impairing the quality of results for this section in both campaigns. 
Figure 8: (a) Estimated water discharge and velocity: Section 20 third measurement in the first survey; and (b) Section 19 first measurement in the second survey

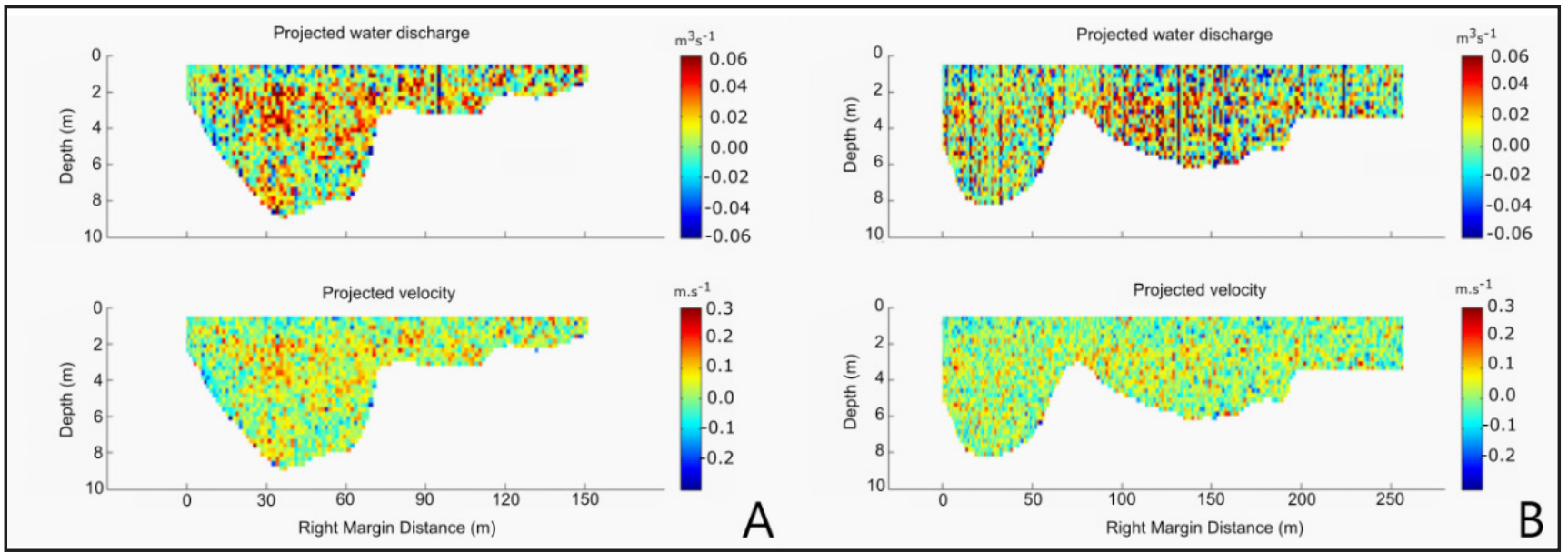

Source: FIPAI

Table 2 - Hydraulic and sedimentological characteristics' measurements of Mogi-Guaçu's reservoir cross sections in the second survey

\begin{tabular}{|c|c|c|c|c|c|c|}
\hline Section & Measurement & $\begin{array}{l}\text { Mean water } \\
\text { discharge } \\
\left(\mathrm{m}^{3} \cdot \mathrm{s}^{-1}\right)\end{array}$ & $\begin{array}{l}\text { Mean Velocity } \\
\left(\mathrm{m} \cdot \mathrm{s}^{-1}\right)\end{array}$ & $\begin{array}{l}\text { Width } \\
\text { (m) }\end{array}$ & $\begin{array}{l}\text { Mean Depth } \\
\text { (m) }\end{array}$ & $\begin{array}{c}\mathrm{SSC} \\
\left(\mathrm{mg} \cdot \mathrm{L}^{-1}\right)\end{array}$ \\
\hline \multirow{4}{*}{ Section 1} & S1-1 & 24.22 & 0.064 & 61.29 & 6.45 & \multirow{4}{*}{59.000} \\
\hline & S1-2 & 21.83 & 0.06 & 58.57 & 6.34 & \\
\hline & S1-3 & 21.65 & 0.058 & 60.1 & 6.32 & \\
\hline & S1-4 & 22.31 & 0.064 & 57.74 & 6.20 & \\
\hline \multirow{4}{*}{ Section 6} & S6-1 & 22.64 & 0.086 & 48.02 & 5.91 & \multirow{4}{*}{52.500} \\
\hline & S6-2 & 22.95 & 0.081 & 49.4 & 6.21 & \\
\hline & S6-3 & 24.93 & 0.086 & 50.41 & 6.10 & \\
\hline & S6-4 & 22.5 & 0.076 & 51.27 & 6.25 & \\
\hline \multirow{4}{*}{ Section 8} & s8-1 & 21.77 & 0.066 & 58.53 & 6.72 & \multirow{4}{*}{45.000} \\
\hline & S8-2 & 22.03 & 0.057 & 57.04 & 6.69 & \\
\hline & S8-3 & 22.89 & 0.062 & 56.81 & 6.71 & \\
\hline & S8-4 & 22.83 & 0.059 & 58.91 & 6.67 & \\
\hline \multirow{4}{*}{ Section 12} & S12-1 & 27.61 & 0.045 & 117.56 & 6.22 & \multirow{4}{*}{35.500} \\
\hline & S12-2 & 22.76 & 0.04 & 120.81 & 6.13 & \\
\hline & S12-3 & 24.8 & 0.042 & 118.59 & 6.18 & \\
\hline & S12-4 & 20.76 & 0.038 & 128.8 & 5.93 & \\
\hline Section 16 & S16-4 & 21.77 & 0.013 & 667.56 & 4.40 & 25.000 \\
\hline \multirow{4}{*}{ Section 20} & S2O-1 & 27.39 & 0.033 & 160.11 & 5.36 & \multirow{4}{*}{19.670} \\
\hline & S2O-2 & 24.87 & 0.038 & 158.68 & 5.40 & \\
\hline & $\mathrm{S} 2 \mathrm{O}-3$ & 22.06 & 0.026 & 152.33 & 5.59 & \\
\hline & $\mathrm{S} 2 \mathrm{O}-4$ & 22.62 & 0.037 & 154.81 & 5.69 & \\
\hline
\end{tabular}

Source: FIPAI (2015) 
Table 3 - Hydraulic characteristics' measurements of Mogi-Guaçu's reservoir in the second survey

\begin{tabular}{|c|c|c|c|c|c|c|}
\hline Section & Measurement & $\begin{array}{c}\text { Mean water } \\
\text { discharge }\left(\mathrm{m}^{3} \cdot \mathrm{s}^{-1}\right)\end{array}$ & $\begin{array}{l}\text { Mean Velocity } \\
\left(\mathrm{m} \cdot \mathrm{s}^{-1}\right)\end{array}$ & Width (m) & Mean Depth (m) & $\begin{array}{c}\mathrm{SSC} \\
\left(\mathrm{mg} \cdot \mathrm{L}^{-1}\right)\end{array}$ \\
\hline \multirow[t]{3}{*}{ Section 1} & S1-1 & 21.09 & 0.051 & 51.31 & 7.54 & \\
\hline & S1-2 & 16.8 & 0.05 & 54.8 & 7.46 & 20.000 \\
\hline & S1-3 & 20.45 & 0.051 & 56.83 & 7.36 & \\
\hline \multirow[t]{3}{*}{ Section 6} & S6-1 & 20.01 & 0.051 & 52.13 & 6.69 & \\
\hline & s6-2 & 19.38 & 0.056 & 55.44 & 6.45 & 15.500 \\
\hline & S6-3 & 19.37 & 0.054 & 54.36 & 6.62 & \\
\hline \multirow[t]{3}{*}{ Section 8} & S8-1 & 20.78 & 0.053 & 58.54 & 6.88 & \\
\hline & s8-2 & 20.72 & 0.053 & 56.93 & 7.23 & 14.000 \\
\hline & s8-3 & 24.36 & 0.06 & 57.77 & 7.11 & \\
\hline \multirow[t]{3}{*}{ Section 12} & S12-1 & 28.53 & 0.042 & 113.27 & 6.79 & \\
\hline & $\mathrm{S} 12-2$ & 26.5 & 0.038 & 118.21 & 6.50 & 20.500 \\
\hline & S12-3 & 28.67 & 0.04 & 112.93 & 6.75 & \\
\hline \multirow[t]{3}{*}{ Section 16} & S16-1 & 40.38 & 0.022 & 616.41 & 3.15 & \\
\hline & S16-2 & 35.21 & 0.024 & 625.81 & 2.99 & 14.862 \\
\hline & S16-3 & 41.26 & 0.021 & 622.87 & 3.27 & \\
\hline \multirow[t]{3}{*}{ Section 19} & S19-1 & 24.51 & 0.025 & 258.3 & 6.13 & \\
\hline & $\mathrm{S} 19-2$ & 23.47 & 0.015 & 264.95 & 5.93 & 8.942 \\
\hline & S19-3 & 18.08 & 0.018 & 264.92 & 5.96 & \\
\hline
\end{tabular}

Source: FIPAI (2015)

\subsection{Simulations in the developed computational tool}

The NH Statistic and Sediment Computational Tool (NHSS) has a hydro-sedimentological module and a statistic one that can be selected by the user according to their objectives (Figure 9). In this paper, we present the hydro-sedimentological module that uses Colby's procedure (1957) to estimate the total solid discharge in water bodies (Figure 10). The tool allows the user to enter the data of water discharge $\left(\mathrm{m}^{3} . \mathrm{s}-1\right)$, mean velocity (ms-1), width (m), mean depth (m) and mean concentration (mg.L-1) in the fields highlighted in yellow and the results obtained are shown in the gray fields.

Figure 11 shows the screen with the data used in the computational tool to estimate the total sediment discharge for the first survey and Table 4 presents a summary containing the respective obtained results. The values

Figure 9 - Total sediment discharge estimate screen using Colby's simplified procedure (1957)

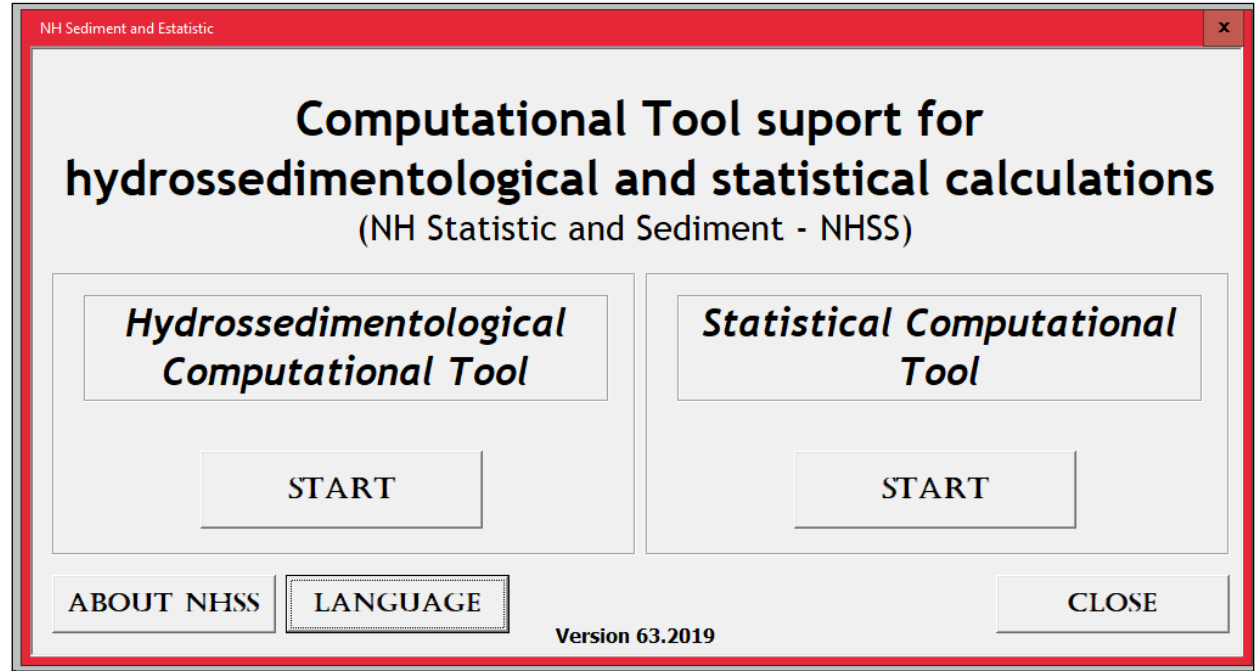

Source: Santos (2019) 
Figure 10 - Total sediment discharge estimate screen using Colby's simplified procedure (1957)

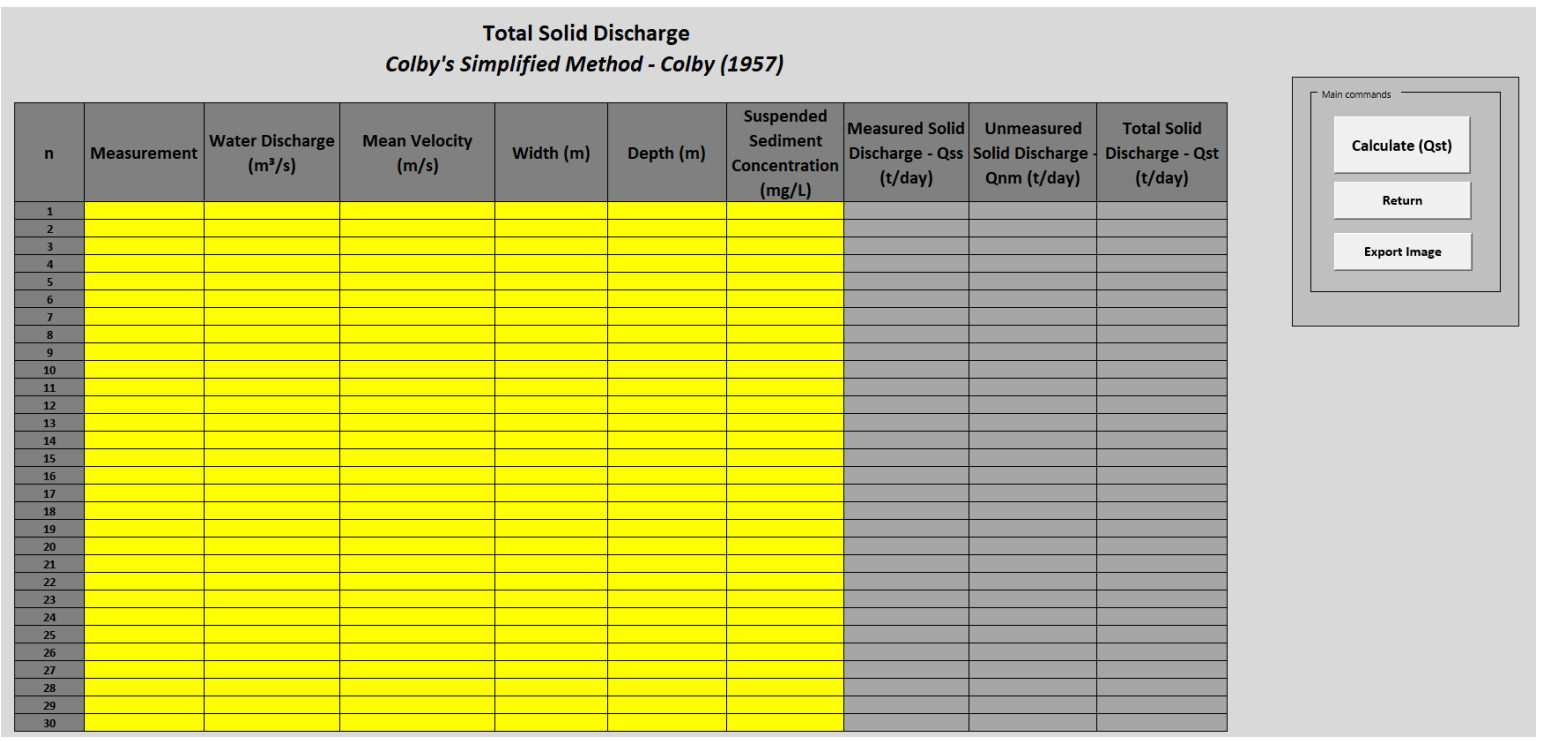

Source: Santos (2019)

of sediment discharge presented mean values in the sections of the Mogi-Guaçu reservoir varying between 117.68 t.day-1 (Section 1) and 42.33 t.day-1 (Section 20). In addition, the Qst decrease along the reservoir was observed mainly in sections 12,16 and 20 due to the increase in the width of the reservoir where there is a reduction in the depth which identifies the formation of a sediment deposition delta. In these sections, the classes of greater granulometry were deposited, reducing the amount of sediment being transported.

In order to compare and verify the temporal variation of the Qst in the Mogi-Guaçu reservoir, Figure 12 shows the screen with the data used in the computational tool to estimate the total sediment discharge for the second survey and Table 5 contains the obtained results.

In this case, it was possible to observe that mean values of total sediment discharge varied between 17.45 t.day-1 (Section 19) and 50.97 t.day-1 (Section 12). The values of Qst presented in Table 5 are significantly lower than the data obtained in survey 1 , precisely because of water discharge and lower suspended sediment concentrations. Besides, this characteristic was expected due to survey 2 being associated to the dry season of the hydrological year.

It should be noted that the highs Qst obtained mainly in section 16 are related to the biggest measured water discharges. It is believed that this increase in water discharge is related to the difficulties in the measurements of the hydraulic characteristics of the section with the ADCP, since the wind speed made it difficult to obtain data. Despite this, the estimates of total sediment discharge by the simplified procedure by Colby (1957) obtained with the NH Statistic and Sediment Computational Tool are consistent between the two surveys.

Figure 11 - Total sediment discharge calculation in different sections (Survey 1)

\begin{tabular}{|c|c|c|c|c|c|c|c|c|c|}
\hline $\mathbf{n}$ & Measurement & $\begin{array}{c}\text { Water Discharge } \\
\left(\mathrm{m}^{3} / \mathrm{s}\right)\end{array}$ & $\begin{array}{l}\text { Mean Velocity } \\
(\mathrm{m} / \mathrm{s})\end{array}$ & Width (m) & Depth (m) & $\begin{array}{c}\text { Suspended } \\
\text { Sediment } \\
\text { Concentration } \\
\text { (mg/L) }\end{array}$ & $\begin{array}{c}\text { Measured Solid } \\
\text { Discharge - Qss } \\
\text { (t/day) }\end{array}$ & $\begin{array}{c}\text { Unmeasured } \\
\text { Solid Discharge } \\
\text { Qnm (t/day) }\end{array}$ & $\begin{array}{c}\text { Total Solid } \\
\text { Discharge - Qst } \\
\text { (t/day) }\end{array}$ \\
\hline 1 & s1-1 & 24.220 & 0.064 & 61.290 & 6.450 & 59.000 & 123.4639 & 3.338 & 126.801 \\
\hline 2 & $51-2$ & 21.830 & 0.060 & 58.570 & 6.339 & 59.000 & 111.2806 & 2.768 & 114.049 \\
\hline 3 & $51-3$ & 21.650 & 0.058 & 60.100 & 6.316 & 59.000 & 110.3630 & 2.637 & 113.000 \\
\hline 4 & $51-4$ & 22.310 & 0.064 & 57.740 & 6.198 & 59.000 & 113.7275 & 3.144 & 116.872 \\
\hline 5 & $56-1$ & 22.640 & 0.086 & 48.020 & 5.907 & 52.500 & 102.6950 & 4.726 & 107.421 \\
\hline 6 & $56-2$ & 22.950 & 0.081 & 49.400 & 6.210 & 52.500 & 104.1012 & 4.263 & 108.364 \\
\hline 7 & $56-3$ & 24.930 & 0.086 & 50.410 & 6.102 & 52.500 & 113.0825 & 4.961 & 118.043 \\
\hline 8 & $56-4$ & 22.500 & 0.076 & 51.270 & 6.247 & 52.500 & 102.0600 & 3.847 & 105.907 \\
\hline 9 & $58-1$ & 21.770 & 0.066 & 58.530 & 6.725 & 45.000 & 84.6418 & 3.574 & 88.215 \\
\hline 10 & $58-2$ & 22.030 & 0.057 & 57.040 & 6.686 & 45.000 & 85.6526 & 2.545 & 88.198 \\
\hline 11 & 58-3 & 22.890 & 0.062 & 56.810 & 6.711 & 45.000 & 88.9963 & 3.034 & 92.031 \\
\hline 12 & $58-4$ & 22.830 & 0.059 & 58.910 & 6.666 & 45.000 & 88.7630 & 2.830 & 91.593 \\
\hline 13 & S12-1 & 27.610 & 0.045 & 117.560 & 6.223 & 35.500 & 84.6854 & 2.315 & 87.000 \\
\hline 14 & $512-2$ & 22.760 & 0.040 & 120.810 & 6.132 & 35.500 & 69.8095 & 1.837 & 71.647 \\
\hline 15 & $512-3$ & 24.800 & 0.042 & 118.590 & 6.178 & 35.500 & 76.0666 & 2.007 & 78.074 \\
\hline 16 & $512-4$ & 20.760 & 0.038 & 128.800 & 5.926 & 35.500 & 63.6751 & 1.750 & 65.425 \\
\hline 17 & $516-4$ & 21.770 & 0.013 & 667.560 & 4.402 & 25.000 & 47.0232 & 0.491 & 47.514 \\
\hline 18 & $520-1$ & 27.390 & 0.033 & 160.110 & 5.356 & 19.670 & 46.5490 & 1.026 & 47.575 \\
\hline 19 & $520-2$ & 24.870 & 0.038 & 158.680 & 5.395 & 19.670 & 42.2663 & 1.392 & 43.658 \\
\hline 20 & $520-3$ & 22.060 & 0.026 & 152.330 & 5.594 & 19.670 & 37.4907 & 0.678 & 38.168 \\
\hline 21 & $520-4$ & 22.620 & 0.037 & 154.810 & 5.685 & 19.670 & 38.4424 & 1.493 & 39.935 \\
\hline
\end{tabular}


Table 4 - Total sediment discharge data synthesis obtained in the Computational tool NHSS (Survey 1)

\begin{tabular}{|c|c|c|c|c|c|c|}
\hline Sections & Measurement & $\begin{array}{c}\text { Mean water } \\
\text { discharge } \\
\left(\mathrm{m}^{3} \cdot \mathrm{s}^{-1}\right)\end{array}$ & $\mathrm{SS}_{\mathrm{C}}\left(\mathrm{mg} \cdot \mathrm{L}^{-1}\right)$ & $\begin{array}{l}\text { Measured } \\
\text { load - Qss } \\
\left(\text { t.dia }^{-1}\right)\end{array}$ & $\begin{array}{l}\text { Unmeasured } \\
\text { load - Qnm } \\
\left(\text { t.dia }{ }^{-1}\right)\end{array}$ & $\begin{array}{l}\text { Total solid } \\
\text { discharge - } \\
\text { Qst }\left(\text { t.dia }^{-1}\right)\end{array}$ \\
\hline \multirow{4}{*}{ Section 1 (S1) } & S1-1 & 24.22 & \multirow{4}{*}{59.000} & 123.464 & 3.338 & 126.801 \\
\hline & s1-2 & 21.83 & & 111.281 & 2.768 & 114.049 \\
\hline & S1-3 & 21.65 & & 110.363 & 2.637 & 113.000 \\
\hline & S1-4 & 22.31 & & 113.727 & 3.144 & 116.872 \\
\hline \multirow{4}{*}{ Section 6 (S6) } & S6-1 & 22.64 & \multirow{4}{*}{52.500} & 102.695 & 4.726 & 107.421 \\
\hline & S6-2 & 22.95 & & 104.101 & 4.263 & 108.364 \\
\hline & S6-3 & 24.93 & & 113.082 & 4.961 & 118.043 \\
\hline & S6-4 & 22.5 & & 102.060 & 3.847 & 105.907 \\
\hline \multirow{4}{*}{ Section 8 (S8) } & S8-1 & 21.77 & \multirow{4}{*}{45.000} & 84.642 & 3.574 & 88.215 \\
\hline & s8-2 & 22.03 & & 85.653 & 2.545 & 88.198 \\
\hline & S8-3 & 22.89 & & 88.996 & 3.034 & 92.031 \\
\hline & S8-4 & 22.83 & & 88.763 & 2.830 & 91.593 \\
\hline \multirow{4}{*}{ Section 12 (S12) } & S12-1 & 27.61 & \multirow{4}{*}{35.500} & 84.685 & 2.315 & 87.000 \\
\hline & S12-2 & 22.76 & & 69.809 & 1.837 & 71.647 \\
\hline & S12-3 & 24.8 & & 76.067 & 2.007 & 78.074 \\
\hline & S12-4 & 20.76 & & 63.675 & 1.750 & 65.425 \\
\hline \multirow[t]{2}{*}{ Section 16 (S16) } & S16-4 & 21.77 & \multirow[t]{2}{*}{25.000} & 47.023 & 0.491 & 47.514 \\
\hline & S20-1 & 27.39 & & 46.549 & 1.026 & 47.575 \\
\hline \multirow{3}{*}{ Section 20 (S20) } & s20-2 & 24.87 & \multirow{3}{*}{19.670} & 42.266 & 1.392 & 43.658 \\
\hline & S2O-3 & 22.06 & & 37.491 & 0.678 & 38.168 \\
\hline & $\mathrm{S} 2 \mathrm{O}-4$ & 22.62 & & 38.442 & 1.493 & 39.935 \\
\hline
\end{tabular}

Figure 12 - Total sediment discharge calculation in different sections (Survey 2)

\begin{tabular}{|c|c|c|c|c|c|c|c|c|c|}
\hline $\mathbf{n}$ & Measurement & $\begin{array}{c}\text { Water Discharge } \\
\left(\mathrm{m}^{3} / \mathrm{s}\right)\end{array}$ & $\begin{array}{l}\text { Mean Velocity } \\
\qquad(\mathrm{m} / \mathrm{s})\end{array}$ & Width (m) & Depth (m) & $\begin{array}{c}\text { Suspended } \\
\text { Sediment } \\
\text { Concentration } \\
\text { (mg/L) }\end{array}$ & $\begin{array}{c}\text { Measured Solid } \\
\text { Discharge - Qss } \\
\text { (t/day) }\end{array}$ & $\begin{array}{l}\text { Unmeasured } \\
\text { Solid Discharge } \\
\text { Qnm (t/day) }\end{array}$ & $\begin{array}{c}\text { Total Solid } \\
\text { Discharge - Qst } \\
\text { (t/day) }\end{array}$ \\
\hline 1 & S1-1 & 21.090 & 0.051 & 51.310 & 7.544 & 20.000 & 36.4435 & 1.281 & 37.725 \\
\hline 2 & S1-2 & 16.800 & 0.050 & 54.800 & 7.463 & 20.000 & 29.0304 & 1.250 & 30.280 \\
\hline 3 & S1-3 & 20.450 & 0.051 & 56.830 & 7.363 & 20.000 & 35.3376 & 1.352 & 36.690 \\
\hline 4 & $56-1$ & 20.010 & 0.051 & 52.130 & 6.688 & 15.500 & 26.7974 & 1.097 & 27.895 \\
\hline 5 & $56-2$ & 19.380 & 0.056 & 55.440 & 6.454 & 15.500 & 25.9537 & 1.183 & 27.136 \\
\hline 7 & $58-1$ & 20.780 & 0.053 & 58.540 & 6.884 & 14.000 & 25.1355 & 1.274 & 26.409 \\
\hline 8 & $58-2$ & 20.720 & 0.053 & 56.930 & 7.230 & 14.000 & 25.0629 & 1.239 & 26.302 \\
\hline 9 & $58-3$ & 24.360 & 0.060 & 57.770 & 7.107 & 14.000 & 29.4659 & 1.639 & 31.105 \\
\hline 10 & S12-1 & 28.530 & 0.042 & 113.270 & 6.792 & 20.500 & 50.5323 & 1.801 & 52.333 \\
\hline 11 & $S 12-2$ & 26.500 & 0.038 & 118.210 & 6.500 & 20.500 & 46.9368 & 1.233 & 48.170 \\
\hline 12 & S12-3 & 28.670 & 0.040 & 112.930 & 6.745 & 20.500 & 50.7803 & 1.618 & 52.398 \\
\hline 13 & S16-1 & 40.380 & 0.022 & 616.410 & 3.151 & 14.862 & 51.8510 & 0.705 & 52.556 \\
\hline 14 & S16-2 & 35.210 & 0.024 & 625.810 & 2.993 & 14.862 & 45.2123 & 0.878 & 46.091 \\
\hline 15 & S16-3 & 41.260 & 0.021 & 622.870 & 3.272 & 14.862 & 52.9810 & 0.638 & 53.619 \\
\hline 16 & S19-1 & 24.510 & 0.025 & 258.300 & 6.135 & 8.942 & 18.9362 & 0.721 & 19.657 \\
\hline 17 & $\mathrm{~S} 19-2$ & 23.470 & 0.015 & 264.950 & 5.932 & 8.942 & 18.1327 & 0.241 & 18.374 \\
\hline
\end{tabular}

Source: Authors 
Table 5 - Total sediment discharge data synthesis obtained in the Computational tool NHSS (Survey 2)

\begin{tabular}{|c|c|c|c|c|c|c|}
\hline Sections & Measurement & $\begin{array}{c}\text { Mean water } \\
\text { discharge }\left(\mathrm{m}^{3} \cdot \mathrm{s}^{-1}\right)\end{array}$ & $\underset{\left(\mathrm{mg} \mathrm{E}^{-1}\right)}{\mathrm{SS}}$ & $\begin{array}{l}\text { Measured load - } \\
\text { Qss }\left(\mathrm{t}_{\text {. }} \mathrm{dia}^{-1}\right)\end{array}$ & $\begin{array}{l}\text { Unmeasured load - } \\
\text { Qnm (t.dia-1) }\end{array}$ & $\begin{array}{c}\text { Total solid discharge - } \\
\text { Qst (t.dia-1) }\end{array}$ \\
\hline \multirow{3}{*}{$\begin{array}{l}\text { Section } 1 \\
\text { (S1) }\end{array}$} & S1-1 & 21.09 & \multirow{3}{*}{20.000} & 36.444 & 1.281 & 37.725 \\
\hline & S1-2 & 16.8 & & 29.030 & 1.250 & 30.280 \\
\hline & S1-3 & 20.45 & & 35.338 & 1.352 & 36.690 \\
\hline \multirow{3}{*}{$\begin{array}{l}\text { Section } 6 \\
\text { (S6) }\end{array}$} & S6-1 & 20.01 & \multirow{3}{*}{15.500} & 26.797 & 1.097 & 27.895 \\
\hline & s6-2 & 19.38 & & 25.954 & 1.183 & 27.136 \\
\hline & $56-3$ & 19.37 & & 25.940 & 1.293 & 27.233 \\
\hline \multirow{3}{*}{$\begin{array}{l}\text { Section } 8 \\
\text { (S8) }\end{array}$} & S8-1 & 20.78 & \multirow{3}{*}{14.000} & 25.135 & 1.274 & 26.409 \\
\hline & s8-2 & 20.72 & & 25.063 & 1.239 & 26.302 \\
\hline & S8-3 & 24.36 & & 29.466 & 1.639 & 31.105 \\
\hline \multirow{3}{*}{$\begin{array}{l}\text { Section } 12 \\
\text { (S12) }\end{array}$} & S12-1 & 28.53 & \multirow{3}{*}{20.500} & 50.532 & 1.801 & 52.333 \\
\hline & $\mathrm{S} 12-2$ & 26.5 & & 46.937 & 1.233 & 48.170 \\
\hline & S12-3 & 28.67 & & 50.780 & 1.618 & 52.398 \\
\hline \multirow{3}{*}{$\begin{array}{l}\text { Section } 16 \\
\text { (S16) }\end{array}$} & S16-1 & 40.38 & \multirow{3}{*}{14.862} & 51.851 & 0.705 & 52.556 \\
\hline & $\mathrm{S} 16-2$ & 35.21 & & 45.212 & 0.878 & 46.091 \\
\hline & S16-3 & 41.26 & & 52.981 & 0.638 & 53.619 \\
\hline \multirow{3}{*}{$\begin{array}{l}\text { Section } 19 \\
\text { (S19) }\end{array}$} & S19-1 & 24.51 & \multirow{3}{*}{$8, .42$} & 18.936 & 0.721 & 19.657 \\
\hline & S19-2 & 23.47 & & 18.133 & 0.241 & 18.374 \\
\hline & S19-3 & 18.08 & & 13.968 & 0.360 & 14.328 \\
\hline
\end{tabular}

\subsection{Verification of the total sediment discharge results obtained in the computational tool - $\mathrm{NH}$ Statistic and Sediment}

For the comparison of the total sediment discharge results obtained by the NH Statistic and Sediment computational tool, they were compared with two other computational tools: WinTSR (ROSA; BERLING, 2002) and NH Sediment (MIRANDA, 2015). The results obtained from the simulations in these two software (WinTSR and $\mathrm{NH}$ Sediment) as well as the comparison with the NH Statistic and Sediment (NHSS) data are presented in Tables 6 to 9. Comparing the Qst values obtained by the developed computational tool and the WinTSR it was possible to observe a low percentage difference between the applications, with an average of $-0.30 \%$. In relation to NH Sediment, the average percentage difference was $0.73 \%$ for the first survey. Despite the greater difference between the tools NH Statistic and Sediment and NH Sediment, in both cases this difference is minimal and does not mitigate future sediment transport studies in the region and shows the accuracy of the developed tool.

Analyzing the data from survey 2, it was observed that, as in survey 1, the Qst differences between the software were minimal, with mean values of $-0.30 \%$ and $0.89 \%$, respectively, in relation to WinTSR and NH Sediment.

Table 10 presents the comparisons of the sediment discharge involving the two surveys in ascending order regarding the Qst obtained in the developed computatio- nal tool. In addition, WinTSR was adopted as standard comparison software due to its wide use in studies such as Scapin, Paiva and Beling (2007), Santos et al. (2012), Miranda (2015).

Qst values were ordered in relation to the WinTSR software but no percentage difference pattern was found. In other words, there are major and minor errors evenly distributed among the results. This indicates that the total sediment discharge results provided by the computational tool are consistent and valid.

Thus, it was possible to observe that the computational tool NH Statistic and Sediment presented values of total sediment discharge compatible with the other software. Comparisons with WinTSR showed that the developed tool NHSS provided better results than the NH Sediment tool, since the maximum percentage difference between WinTSR and NHSS was $-0.49 \%$ while between WinTSR and NH Sediment was $-1.66 \%$. Despite this, the results among all the software are satisfactory and meet the objective of estimating the total sediment discharge with maximum reliability.

Overall, the computational tool NH Statistic and Sediment allows the calculation of the Qst of several sections/ locations in a single click, while in WinTSR this parameter is obtained from section to section. In addition, unlike WinTSR and NH Sediment, which are software aimed at hydro-sedimentology, the NH Statistic and Sediment computational tool is a multidisciplinary software that also performs statistical calculations, at no cost, open 
Table 6 - Comparison between the total sediment discharge values (Qst) obtained in the NHSS computational tool and WinTSR software (Survey 1)

\begin{tabular}{|c|c|c|c|c|}
\hline Section & Qst - NHSS (t.day-1) & Qst - WinTSR (t.day-1) & $\begin{array}{c}\text { Difference between Qst } \\
\text { (WinTSR and NHSS) (t.day-1) }\end{array}$ & $\begin{array}{l}\text { Difference between Qst } \\
\text { (WinTSR and NHSS) (\%) }\end{array}$ \\
\hline S1-1 & 126.801 & 126.467 & -0.335 & $-0.26 \%$ \\
\hline S1-2 & 114.049 & 113.768 & -0.281 & $-0.25 \%$ \\
\hline S1-3 & 113.000 & 112.731 & -0.270 & $-0.24 \%$ \\
\hline S1-4 & 116.872 & 116.556 & -0.315 & $-0.27 \%$ \\
\hline S6-1 & 107.421 & 106.979 & -0.442 & $-0.41 \%$ \\
\hline S6-2 & 108.364 & 107.961 & -0.404 & $-0.37 \%$ \\
\hline S6-3 & 118.043 & 117.580 & -0.464 & $-0.39 \%$ \\
\hline S6-4 & 105.907 & 105.538 & -0.369 & $-0.35 \%$ \\
\hline S8-1 & 88.215 & 87.856 & -0.359 & $-0.41 \%$ \\
\hline S8-2 & 88.198 & 87.934 & -0.264 & $-0.30 \%$ \\
\hline s8-3 & 92.031 & 91.722 & -0.309 & $-0.34 \%$ \\
\hline S8-4 & 91.593 & 91.216 & -0.377 & $-0.41 \%$ \\
\hline S12-1 & 87.000 & 86.761 & -0.239 & $-0.28 \%$ \\
\hline S12-2 & 71.647 & 71.453 & -0.194 & $-0.27 \%$ \\
\hline S12-3 & 78.074 & 77.864 & -0.210 & $-0.27 \%$ \\
\hline S12-4 & 65.425 & 65.239 & -0.187 & $-0.29 \%$ \\
\hline S16-4 & 47.514 & 47.456 & -0.058 & $-0.12 \%$ \\
\hline S2O-1 & 47.575 & 47.470 & -0.105 & $-0.22 \%$ \\
\hline S2O-2 & 43.658 & 43.520 & -0.138 & $-0.32 \%$ \\
\hline S2O-3 & 38.168 & 38.094 & -0.074 & $-0.19 \%$ \\
\hline S2O-4 & 39.935 & 39.782 & -0.153 & $-0.38 \%$ \\
\hline
\end{tabular}

Table 7 - Comparison between the total sediment discharge values (Qst) obtained in the NHSS computational tool and NH Sediment computation tool (Survey 1 )

\begin{tabular}{|c|c|c|c|c|}
\hline Section & $\begin{array}{l}\text { Qst - NHSS } \\
\left(\text { t.day }^{-1}\right)\end{array}$ & $\begin{array}{l}\text { Qst - NH Sediment } \\
\left(\text { t.day }^{-1}\right)\end{array}$ & $\begin{array}{l}\text { Difference between Qst (NH } \\
\text { Sediment e NHSS) (t.day }{ }^{-1} \text { ) }\end{array}$ & $\begin{array}{l}\text { Difference between Qst (NH } \\
\text { Sediment e NHSS) (\%) }\end{array}$ \\
\hline S1-1 & 126.801 & 127.580 & 0.779 & $0.61 \%$ \\
\hline S1-2 & 114.049 & 114.721 & 0.672 & $0.59 \%$ \\
\hline S1-3 & 113.000 & 113.654 & 0.654 & $0.58 \%$ \\
\hline S1-4 & 116.872 & 117.605 & 0.734 & $0.62 \%$ \\
\hline S6-1 & 107.421 & 108.309 & 0.888 & $0.82 \%$ \\
\hline S6-2 & 108.364 & 109.202 & 0.838 & $0.77 \%$ \\
\hline S6-3 & 118.043 & 118.976 & 0.933 & $0.78 \%$ \\
\hline S6-4 & 105.907 & 106.699 & 0.791 & $0.74 \%$ \\
\hline S8-1 & 88.215 & 89.041 & 0.825 & $0.93 \%$ \\
\hline s8-2 & 88.198 & 88.842 & 0.644 & $0.73 \%$ \\
\hline S8-3 & 92.031 & 92.760 & 0.729 & $0.79 \%$ \\
\hline S8-4 & 91.593 & 92.294 & 0.701 & $0.76 \%$ \\
\hline S12-1 & 87.000 & 87.636 & 0.636 & $0.73 \%$ \\
\hline S12-2 & 71.647 & 72.184 & 0.538 & $0.74 \%$ \\
\hline S12-3 & 78.074 & 78.646 & 0.572 & $0.73 \%$ \\
\hline S12-4 & 65.425 & 65.951 & 0.526 & $0.80 \%$ \\
\hline S16-4 & 47.514 & 47.734 & 0.220 & $0.46 \%$ \\
\hline S2O-1 & 47.575 & 47.884 & 0.309 & $0.65 \%$ \\
\hline s2O-2 & 43.658 & 44.047 & 0.389 & $0.88 \%$ \\
\hline S2O-3 & 38.168 & 38.403 & 0.235 & $0.61 \%$ \\
\hline S2O-4 & 39.935 & 40.369 & 0.434 & $1.08 \%$ \\
\hline
\end{tabular}


Table 8 - Comparison between the total sediment discharge values (Qst) obtained in the NHSS computational tool and WinTSR software (Survey 2)

\begin{tabular}{ccccc}
\hline Section & $\begin{array}{c}\text { Qst - NHSS } \\
\left(\text { t.day }{ }^{1}\right)\end{array}$ & $\begin{array}{c}\text { Qst - WinTSR } \\
\left(\text { t.day }^{-1}\right)\end{array}$ & $\begin{array}{c}\text { Difference between Qst (WinTSR } \\
\text { and NHSS) (t.day })^{-1}\end{array}$ & $\begin{array}{c}\text { Difference between Qst (WinTSR } \\
\text { and NHSS) } \% \text { ) }\end{array}$ \\
\hline S1-1 & 37.725 & 37.596 & -0.129 & $-0.34 \%$ \\
S1-2 & 30.280 & 30.156 & -0.125 & $-0.41 \%$ \\
S1-3 & 36.690 & 36.555 & -0.135 & $-0.37 \%$ \\
S6-1 & 27.895 & 27.787 & -0.107 & $-0.39 \%$ \\
S6-2 & 27.136 & 27.027 & -0.109 & $-0.40 \%$ \\
S6-3 & 27.233 & 27.109 & -0.124 & $-0.46 \%$ \\
S8-1 & 26.409 & 26.287 & -0.122 & $-0.46 \%$ \\
S8-2 & 26.302 & 26.183 & -0.119 & $-0.45 \%$ \\
S8-3 & 31.105 & 30.952 & -0.153 & $-0.49 \%$ \\
S12-1 & 52.333 & 52.146 & -0.187 & $-0.36 \%$ \\
S12-2 & 48.170 & 48.044 & -0.126 & $-0.26 \%$ \\
S12-3 & 52.398 & 52.229 & -0.169 & $-0.32 \%$ \\
S16-1 & 52.556 & 52.593 & 0.037 & $0.07 \%$ \\
S16-2 & 46.091 & 46.138 & 0.047 & $0.10 \%$ \\
S16-3 & 53.619 & 53.653 & 0.034 & $0.06 \%$ \\
S19-1 & 19.657 & 19.578 & -0.079 & $-0.41 \%$ \\
S19-2 & 18.374 & 18.342 & -0.032 & $-0.17 \%$ \\
S19-3 & 14.328 & 14.285 & -0.043 & $-0.30 \%$ \\
\hline
\end{tabular}

Table 9 - Comparison between the total sediment discharge values (Qst) obtained in the NHSS computational tool and NH Sediment computation tool (Survey 2)

\begin{tabular}{|c|c|c|c|c|}
\hline Section & $\begin{array}{l}\text { Qst - NHSS } \\
\left(\text { t.day }^{-1}\right)\end{array}$ & $\begin{array}{l}\text { Qst - NH Sediment } \\
\left(\text { t.day }^{-1}\right)\end{array}$ & $\begin{array}{l}\text { Difference between Qst (NH } \\
\left.\text { Sediment and NHSS) (t.day }{ }^{-1}\right)\end{array}$ & $\begin{array}{l}\text { Difference between Qst (NH } \\
\text { Sediment and NHSS) (\%) }\end{array}$ \\
\hline S1-1 & 37.725 & 38.050 & 0.325 & $0.85 \%$ \\
\hline S1-2 & 30.280 & 30.599 & 0.318 & $1.04 \%$ \\
\hline S1-3 & 36.690 & 37.030 & 0.340 & $0.92 \%$ \\
\hline S6-1 & 27.895 & 28.164 & 0.270 & $0.96 \%$ \\
\hline $56-2$ & 27.136 & 27.401 & 0.264 & $0.96 \%$ \\
\hline s6-3 & 27.233 & 27.540 & 0.307 & $1.11 \%$ \\
\hline S8-1 & 26.409 & 26.712 & 0.303 & $1.13 \%$ \\
\hline S8-2 & 26.302 & 26.596 & 0.295 & $1.11 \%$ \\
\hline S8-3 & 31.105 & 31.464 & 0.359 & $1.14 \%$ \\
\hline S12-1 & 52.333 & 52.841 & 0.508 & $0.96 \%$ \\
\hline S12-2 & 48.170 & 48.524 & 0.355 & $0.73 \%$ \\
\hline S12-3 & 52.398 & 52.867 & 0.469 & $0.89 \%$ \\
\hline S16-1 & 52.556 & 52.784 & 0.228 & $0.43 \%$ \\
\hline S16-2 & 46.091 & 46.363 & 0.273 & $0.59 \%$ \\
\hline S16-3 & 53.619 & 53.830 & 0.211 & $0.39 \%$ \\
\hline S19-1 & 19.657 & 19.898 & 0.241 & $1.21 \%$ \\
\hline S19-2 & 18.374 & 18.475 & 0.101 & $0.55 \%$ \\
\hline S19-3 & 14.328 & 14.467 & 0.139 & $0.96 \%$ \\
\hline
\end{tabular}


Table 10 - Comparison between the total sediment discharge values (Qst) obtained in the NHSS computational tool and NH Sediment computation tool (Survey 2)

\begin{tabular}{|c|c|c|c|c|c|c|}
\hline $\begin{array}{l}\text { Measure- } \\
\text { ment }\end{array}$ & $\begin{array}{l}\text { Qst - NHSS } \\
\text { [t.day-1] }\end{array}$ & $\begin{array}{l}\text { Qst- } \\
\text { WinTSR } \\
\text { [t.day-1] }\end{array}$ & $\begin{array}{l}\text { Qst - NH } \\
\text { Sediment } \\
\text { [t.day-1] }\end{array}$ & $\begin{array}{c}\text { Difference between } \\
\text { WinTSR and NHSS } \\
\text { [\%] }\end{array}$ & $\begin{array}{c}\text { Difference between } \\
\text { NH Sediment and } \\
\text { NHSS [\%] }\end{array}$ & $\begin{array}{l}\text { Difference between } \\
\text { WinTSR and NH } \\
\text { Sediment [\%] }\end{array}$ \\
\hline C2-S19-3 & 14.33 & 14.29 & 14.47 & $-0.30 \%$ & $0.96 \%$ & $-1.28 \%$ \\
\hline C2-S19-2 & 18.37 & 18.34 & 18.47 & $-0.17 \%$ & $0.55 \%$ & $-0.72 \%$ \\
\hline C2-S19-1 & 19.66 & 19.58 & 19.90 & $-0.41 \%$ & $1.21 \%$ & $-1.63 \%$ \\
\hline C2-58-2 & 26.30 & 26.18 & 26.60 & $-0.45 \%$ & $1.11 \%$ & $-1.58 \%$ \\
\hline C2-S8-1 & 26.41 & 26.29 & 26.71 & $-0.46 \%$ & $1.13 \%$ & $-1.62 \%$ \\
\hline C2-S6-2 & 27.14 & 27.03 & 27.40 & $-0.40 \%$ & $0.96 \%$ & $-1.38 \%$ \\
\hline$c 2-56-3$ & 27.23 & 27.11 & 27.54 & $-0.46 \%$ & $1.11 \%$ & $-1.59 \%$ \\
\hline C2-S6-1 & 27.89 & 27.79 & 28.16 & $-0.39 \%$ & $0.96 \%$ & $-1.36 \%$ \\
\hline C2-S1-2 & 30.28 & 30.16 & 30.60 & $-0.41 \%$ & $1.04 \%$ & $-1.47 \%$ \\
\hline C2-58-3 & 31.10 & 30.95 & 31.46 & $-0.49 \%$ & $1.14 \%$ & $-1.66 \%$ \\
\hline C2-S1-3 & 36.69 & 36.56 & 37.03 & $-0.37 \%$ & $0.92 \%$ & $-1.30 \%$ \\
\hline C2-S1-1 & 37.72 & 37.60 & 38.05 & $-0.34 \%$ & $0.85 \%$ & $-1.21 \%$ \\
\hline C1-S20-3 & 38.17 & 38.09 & 38.40 & $-0.19 \%$ & $0.61 \%$ & $-0.81 \%$ \\
\hline C1-S20-4 & 39.94 & 39.78 & 40.37 & $-0.38 \%$ & $1.08 \%$ & $-1.48 \%$ \\
\hline C1-S20-2 & 43.66 & 43.52 & 44.05 & $-0.32 \%$ & $0.88 \%$ & $-1.21 \%$ \\
\hline C2-S16-2 & 46.09 & 46.14 & 46.36 & $0.10 \%$ & $0.59 \%$ & $-0.49 \%$ \\
\hline C1-S16-4 & 47.51 & 47.46 & 47.73 & $-0.12 \%$ & $0.46 \%$ & $-0.59 \%$ \\
\hline C1-S20-1 & 47.58 & 47.47 & 47.88 & $-0.22 \%$ & $0.65 \%$ & $-0.87 \%$ \\
\hline C2-S12-2 & 48.17 & 48.04 & 48.52 & $-0.26 \%$ & $0.73 \%$ & $-1.00 \%$ \\
\hline C2-S12-1 & 52.33 & 52.15 & 52.84 & $-0.36 \%$ & $0.96 \%$ & $-1.33 \%$ \\
\hline C2-S12-3 & 52.40 & 52.23 & 52.87 & $-0.32 \%$ & $0.89 \%$ & $-1.22 \%$ \\
\hline C2-S16-1 & 52.56 & 52.59 & 52.78 & $0.07 \%$ & $0.43 \%$ & $-0.36 \%$ \\
\hline C2-S16-3 & 53.62 & 53.65 & 53.83 & $0.06 \%$ & $0.39 \%$ & $-0.33 \%$ \\
\hline C1-S12-4 & 65.43 & 65.24 & 65.95 & $-0.29 \%$ & $0.80 \%$ & $-1.09 \%$ \\
\hline C1-S12-2 & 71.65 & 71.45 & 72.18 & $-0.27 \%$ & $0.74 \%$ & $-1.02 \%$ \\
\hline C1-S12-3 & 78.07 & 77.86 & 78.65 & $-0.27 \%$ & $0.73 \%$ & $-1.00 \%$ \\
\hline C1-S12-1 & 87.00 & 86.76 & 87.64 & $-0.28 \%$ & $0.73 \%$ & $-1.01 \%$ \\
\hline C1-S8-2 & 88.20 & 87.93 & 88.84 & $-0.30 \%$ & $0.73 \%$ & $-1.03 \%$ \\
\hline C1-S8-4 & 91.59 & 91.22 & 92.29 & $-0.41 \%$ & $0.76 \%$ & $-1.18 \%$ \\
\hline C1-S8-3 & 92.03 & 91.72 & 92.76 & $-0.34 \%$ & $0.79 \%$ & $-1.13 \%$ \\
\hline C1-S6-4 & 105.91 & 105.54 & 106.70 & $-0.35 \%$ & $0.74 \%$ & $-1.10 \%$ \\
\hline C1/S6-1 & 107.42 & 106.98 & 108.31 & $-0.41 \%$ & $0.82 \%$ & $-1.24 \%$ \\
\hline C1/S6-2 & 108.36 & 107.96 & 109.20 & $-0.37 \%$ & $0.77 \%$ & $-1.15 \%$ \\
\hline C1/S1-3 & 113.00 & 112.73 & 113.65 & $-0.24 \%$ & $0.58 \%$ & $-0.82 \%$ \\
\hline C1/S1-2 & 114.05 & 113.77 & 114.72 & $-0.25 \%$ & $0.59 \%$ & $-0.84 \%$ \\
\hline C1/S1-4 & 116.87 & 116.56 & 117.61 & $-0.27 \%$ & $0.62 \%$ & $-0.90 \%$ \\
\hline C1-S6-3 & 118.04 & 117.58 & 118.98 & $-0.39 \%$ & $0.78 \%$ & $-1.19 \%$ \\
\hline $\mathrm{C} 1 / \mathrm{S} 1-1$ & 126.80 & 126.47 & 127.58 & $-0.26 \%$ & $0.61 \%$ & $-0.88 \%$ \\
\hline
\end{tabular}




\section{Concluding Remarks}

The results of total solid discharge obtained with the developed computational tool characterize the transportation of sediments in water bodies and allow the identification of deposition spots and temporal variations in the sediment discharge.

In addition, the NH Statistic and Sediment computational tool achieves results consistent with other software and it can be said that, besides being reliable, it has a user-friendly interface and presents an user manual for all the tests and methods implemented, which makes its use simple and practical.

All in all, it is also important to note that the methodology used in the case study can be replicated to other sites, providing better information for the management and planning of water resources.

\section{Acknowledgments}

The authors are grateful to AES Tietê S.A. company, which financially supported the data collection through the Program for Research and Development of Electric Power Sector, and Foundation for the Enhancement of Research and Industrial Improvement (FIPAI), Higher Education Personnel Improvement Coordination, National Council for Scientific and Technological Development, and Hydrometric Group of Center of Water Resources and Environmental Studies of São Carlos Engineering School at University of São Paulo.

\section{References}

AES TIETÊ. Pequena central hidrelétrica Mogi-Guaçu [internet]. 2017 [cited 2018 set 27]. Available from: https:// www.aestiete.com.br/quem-somos/nossas-plantas.

ALONSO, C. V.; NEIBLinG, W. H.; FOSTER, G. R. Estimating sediment transport capacity in watershed modeling. Transactions of the American Society of Agricultural and Biological Engineers. 1981,24(5):12111220.

AMERICAN PUBLIC HEALTH ASSOCIATION (APHA). Standard methods for examination of water and wastewater. 19th ed. Washington: APHA;1995.

BRANCO, S. M.; ROCHA, A. A. Poluição, proteção e usos múltiplos de represas. São Paulo: Edgard Blucher; CETESB; 1977.

CARVALHO, N. O. Hidrossedimentologia prática. 2.ed. Rio de Janeiro: Interciência; 2008.

COLBY, B. R. Relationship of unmeasured sediment discharge to mean velocity. Transactions, American Geophysical Union. 1957,38(5):708-717.
COLBY, B. R.; HEMBREE, C. H. Computations of total sediment discharge Niobrara River near Cody, Nebraska. Washington: United States Government Printing Office; 1955.

COMITÊ DA BACIA HIDROGRÁFICA DO RIO MOGIGUAÇU (CBH-MOGI). Plano da bacia hidrográfica 2008-2011. São Paulo: CBH Mogi; 2008.

CURTIS, W. F.; CULbERTSON, J. K.; CHASE, E. B. Fluvial-sediment discharge to the oceans from the conterminous United States: geological survey circular 670. Washington: Department of the Interior; U. S. Geological Survey;1973.

FUNDAÇÃO PARA O INCREMENTO DA PESQUISA E DO APERFEIÇOAMENTO INDUSTRIAL. Desenvolvimento, validação e aplicação de um modelo tridimensional de transporte de sedimentos em reservatório aplicado ao cálculo e elaboração de projeções futuras de geração hidrelétrica. São Carlos;2015 (Relatório de projeto P\&D).

GOLTERMAN, H. L.; SLY, P. G.; THOMAS, R. L. Study of the relationship between water quality and sediment transport. Paris: UNESCO; 1983.

HOLEMAN, J. N. The Sediment yield of major rivers of the world. Water Resources Research. 1968,4(4): 737-747.

LIMA, J. E. F. W.; SILVA, E. M. Seleção de modelos para o traçado de curvas granulométricas de sedimentos em suspensão em rios. Revista Brasileira de Engenharia Agrícola e Ambiental. 2007, 11(1):101-107.

MIRANDA, R. B. Ferramenta computacional para a estimativa de parâmetros hidrossedimentológicos em reservatório: estudo de caso da $\mathrm{PCH}$ Mogi-Guaçu (SP) [thesis]. São Carlos: Escola de Engenharia de São Carlos/ USP;2015.226p.

MITCHELL, M. et al. Software Engauge digitizer: version 10.11. 2018 [cited 2018 nov 24]. Available from https://markummitchell.github.io/engauge-digitizer/.

MULLER, A. C. Hidrelétricas, meio ambiente e desenvolvimento. São Paulo: Makron Books; 1995.

AIVA, J. B. D. Avaliação dos modelos matemáticos de cálculo do transporte de sedimentos em rios [thesis]. São Carlos: Escola de Engenharia de São Carlos/ USP;1988.315p.

PAIVA, J. B. D. Métodos de cálculo do transporte de sedimentos em rios. In: PAIVA, J. B. D.; PAIVA, E. M. C. D. (Org.) Hidrologia aplicada à gestão de pequenas bacias hidrográficas. Porto Alegre: ABRH; 2001. Cap. 12, p. 313-364. 
ROSA, L. H.; BERLING, F. A. Software WinTSR. Santa Maria: Centro de tecnologia. Departamento de Hidráulica e Saneamento; Universidade Federal de Santa Maria; 2002.

SANTOS, B. B., ALVES SOBRINHO, T.; SOUZA, J. S.; CARVAlHO, G. A.; POMPEU, R. M.; COUTO, C. B. Avaliação de métodos de estimativas de descarga sólida de leito em rios. In: POLETO, C.; PLETSCH, A. L.; MELLO, E. L.; CARVAlho, N. O. (Org.) X Encontro Nacional de Engenharia de Sedimentos: artigos selecionados. Porto Alegre: ABRH; 2012. Cap. 26, p. 345-355.

SANTOS, B. B.; MIRANDA, R. B.; ESTIGONI, M. V.; VILLELA, J. M.; MAUAD, F. F. Evaluation of the laser diffraction method for the measurement of suspended sediment concentration in Mogi-Guaçu reservoir (São Paulo, Brazil). International Journal of River Basin Management. 2018,17(1):89-99.

SCAPIN, J.; PAIVA, J. B. D. D.; BELING, F. A. Avaliação de métodos de cálculo do transporte de sedimentos. Revista Brasileira de Recursos Hídricos. 2007,12(4):5-21.

SILVA, R. C. V.; WILSON JÚNIOR., G. Hidráulica fluvial. Rio de Janeiro: COPPE/UFRJ; 2005.

SYVITSKI, J. P. M.; VÖRÖSMARTY, C. J.; KETTNER, A. J.; GREEN P. Impact of humans on the flux of terrestrial sediment to the global coastal ocean. Science, 2005, 308(5720):376-380.

VANONI, V. A. Sediment transportation Mechanics. In: GARCIA, M.H.(Ed.) Sedimentation engineering: processes, measurements, modeling, and practices. Reston: ASCE; 2008. Cap. 2, p. 17-292. (The ASCE manuals and reports on engineering practice, n.110). 